\title{
Correction by contrastive focus ${ }^{*}$
}

\author{
Anita Steube \\ Universität Leipzig \\ steube@rz.uni-leipzig.de
}

\section{Introduction}

'Correction' is the name of a sentence with contrastive focus ${ }^{1}$ the phonological/phonetic realization of which is a single contrastive pitch accent. These sentences predominantly appear in (fictional) dialogues. The first speaker uses grammatical entities against which the next speaker protests with a sentence nearly identical except that it contains a prosodically marked corrective element. This paper makes contrastive focus visible by means of 'KF' (contrastive focus). The focus domain is bracketed: [ ... ]KF. Arabic numbers of sample sentences index first sentences. Capital letters index the focussed syllable of the corresponding correction by the next speaker. Using (1A) the next speaker corrects the time when the treasure was found.

(1) [Kinder fanden im Mai in einem vogtländischen Bergwerk einen wertvollen SILberschatz.] $\mathrm{F}$

(1A) [Am 20. APRIL]KF fanden die Kinder den Schatz. Im Mai wurde er schon AUSgestellt. ${ }^{2}$

When discourse analysts say that meaning is brought about interactively, tuples of sentences followed by one or more sentences with contrastive focus make use of this principle of communication. Interaction ends when no further protest follows. In that case, speakers have tacitly agreed upon the last entity mentioned in the given sentential context, and they have accepted what was expressed as part of their common ground ${ }^{3}$. The sentential context that never was protested against becomes part of common ground, too. So far sentences with contrastive focus follow pragmatic principles. Although they are representative speech acts they interrupt the flow of texts of any type. Only when the correction has been accepted the communicative partners go back to the original type of text and continue the text pattern. This paper, however, is more interested in the internal structure of a correction sentence and in the relation between the pairs of sentences serving as utterances of first and of next speakers. This paper also aims at pointing out the difference in information structure between categorical sentences and next sentences with contrastive focus as their only focus marking which are intended and/or interpreted as corrections.

To interpret a sentence as a correction you need a context which supports this interpretation. There are clear cases and there are borderline cases. Let us compare

\footnotetext{
" The paper is submitted to a special issue of "Theoretical Linguistics", edited by Klaus von Heusinger and Kerstin Schwabe

1 The phonological realization of contrastive focus, contrastive stress embedded in a characteristic prosodic contour, gets a very short characterization in 3.2 .

$2 \mathrm{~F}$ indexes presentational focus with its bracketed focus domain: [ ... ]F.

3 In this paper common ground comprises grammatical knowledge, too.
} 
several examples. Sentence 1A undoubtedly is a correction. Sentences (2A) and (3A), on the other hand, must be regarded as borderline cases. Sentence (2A) without the bracketed context might just as well be interpreted as new information which was added by the next speaker in continuation of the information given in sentence (2). (2A) might even have been produced by the first speaker himself. In that case [In der Eingangszone] does not replace the information on the locality mentioned in (2) by an alternative but may be regarded as a specification of the place [in einem Bergwerk]. The speaker indicates his ability to specify the information hitherto given.

(2) [Kinder fanden am 20. April in einem vogtländischen Bergwerk einen wertvollen SILberschatz.]F

(2A) [In der EINgangszone]KF/F entdeckten sie ihn.

(Die Eingangszone gehört der GeMEINde, die Stollenanlagen den früheren BeTREIbern. Die Unterscheidung hat rechtliche KonseQUENzen.)

Sentence (3A) is an even weaker example for a correction. The lexical entry "finden / to find" expresses an unintended event. But it is open to an interpretation with a preceding action causally linked to the event of "finding". Using / understanding (3A) as a correction fixes the interpretation of to find as an event of finding by chance.

(3) [Kinder fanden am 20. April in einem vogtländischen Bergwerk einen wertvollen SILberschatz]F.

(3A) [AUSgebuddelt]KF/F haben sie ihn, [unter GeRÖLL hervorgeholt]KF, nicht einfach so geFUNden.

When Kai Alter and Ina Mleinek in our project "Intonation and Meaning" of the DFGresearch group 349 conducted production experiments with sentences in unclear contexts many of the subjects did not produce the prosodic contours of corrections. In their interpretation tests the subjects even failed to hear contrastive focus when the contexts did not correspond. Both kinds of tests convinced us that the interpretation of contrastive focus depends on context.

When examples (1) to (3) are interpreted as corrections they protest against the untrue or incorrect representation of a situation. But not all the corrections are directed to the semantic level of their structural description. There are protests against the morphological structure of entities, against their phonological structure or even against the phonetic realization of single elements (cf. (4)),

(4.1) [Anna hat sich mit ihrem NACHbar gestritten]F

(4.1A) Sie hat sich mit ihrem [NachBARN]KF gestritten.

(4.2) [Anna hat sich mit ihrem NACHbarn gestritten.]F

(4.2A) Sie hat sich mit ihrem Nachbarn [ZERstritten]KF.

(4.3) [Das ist aber eine tolle MaCHIne]F.

(4.3A) Eine tolle [MaSCHIne]KF.

or even against all kinds of incorrect quotations (cf. (5)). 
(5) [In einem vogtländischen Bergwerk fanden Kinder beim Spielen einen mittelalterlichen SILberschatz.]F

(5A) [In einem STEINbruch]KF fanden Kinder beim Spielen einen mittelalterlichen Silberschatz.

(5A) is a sentence by Pasch (1983). Correction (5A) restores the quote. In such a case of metalinguistic correction the next speaker is forbidden to change anything but the deviant part(s) for extralinguistic reasons.

The whole variety of examples has to be taken care of when a theory of corrections is to be constructed. In this paper we will first compare the grammatical properties of pairs of first and next sentences (i.e., corrections), and then draw conclusions with respect to their corresponding information structures and finally suggest a model for correctionsentences.

\section{The information structure of categorical sentences}

In order to be able to compare corrections with so-called categorical sentences, we would like to repeat the well-known grammatical properties of the latter:

- The information structure of categorial sentences is divided up into background and focus. For each sentence, the division is made on the basis of the given linguistic and extralinguistic context.

- Background information of German categorical sentences is characterized by scrambled DPs and by the placement of anaphoric pronouns in the so-called Wackernagel-Position.

- DPs expressing background information normally are characterized by definite articles or possessive pronouns. In the rare cases when indefinite articles characterize background information, they are interpreted generally or specifically. Definite articles in the background part of the sentence may have all the interpretations possible: definite, indefinite, general. But when definite articles are to express focus information, they have to refer not only specifically but uniquely.

- The focus domain may be either medium or minimum. Focus accent is realized by the phrasal- or word accent of the deepest embedded verbal complement or verbal adjunct.

- In assertive main clauses, focus is expressed by a characteristic falling prosodic contour.

- The defocused DPs and PPs expressing background information are moved to the left of the focus domain, i.e., outside maximal VP, to be even more precise: to the left of the so-called attitudinal adverbials and particles. There is good reason for attitudinal adverbials and particles to form the right border between background and focus in a sentence. Background information is known or at least accessible to all the communicative partners. But attitudes do not belong to propositional meaning and therefore can never become the mental possession of next speakers.

- The movement of finite German verbs is syntactically motivated. In assertive German main clauses finite verbs are head-moved to $\mathrm{C}^{\circ}$ independent of their status in the information structure of the sentence.

- The so-called topic position in Spec CP can be filled by background as well as focus material. 
- Therefore, background constituents in assertive clauses always are either placed in Spec CP and /or between the finite verb to the left and attitudinal adverbials to the right. Their order is defined by the movement rules for either pronominals or scrambled elements: pronouns precede definite DPs with the exception that the definite subject-DP may precede pronouns or that a pronoun may follow a subject-DP even if it is within the focus domain. Besides, the inner sequence of pronouns and of definite DPs is regulated by cases, and pronominal adverbials normally follow other pronouns, PPs with definite articles normally follow definite DPs.

- Focus information in the topic position can be expressed by either presentational or contrastive focus. Contrastive focus may be the only focus accent in the clause, or it may be part of a so-called Bridge Contour.

- Preferably, the topic position is filled by topics (referring background constituents) or by frame adverbials (which often are counted among topics). But other non-topic constituents are allowed in Spec CP as well. There are speculations that either topics or even a larger class of sentence-initial constituents are thematically connected to the topic of the text and help to organize the inner structure of texts and even characterize types of texts. As far as journalistic reports are concerned, they tend to put focus information in sentence-initial position and thereby put it in the foreground of attention. When more sentences of that kind follow each other, the reader / hearer gets the impression of a rhythmic sequence of important news, and he or she seems to read at a higher speed hurrying from one focussed beginning to the next.

Sentences (6.1) and (6.2) are categorical sentences. The answers (6.1.1) and (6.1.2) repeat the defocused constituents verbally. The focussed constituent can be topicalized (cf.(6.1.2)). The alternative answers in (6.2) are constructed as parts of a continuous text as far as information structure is concerned, i.e. the speaker uses the defocused constituents as expressions of background information realized by means of definite articles or pronouns. The focussed constituents can be topicalized again (cf. (6.2.3), (6.2.4)).

(6.) Wo fanden Kinder einen mittelalterlichen Silberschatz?

(6.1.1) Kinder fanden einen mittelalterlichen Silberschatz [in einem vogtländischen BERGwerk]F.

(6.1.2) [In einem vogtländischen BERGwerk]F fanden Kinder einen mittelalterlichen Silberschatz.

(6.) Wo fanden Kinder einen mittelalterlichen Silberschatz?

(6.2.1) Die Kinder fanden den Schatz [in einem vogtländischen BERGwerk]F.

(6.2.2.) Sie fanden ihn [in einem vogtländischen BERGwerk]F.

(6.2.3.) [In einem vogtländischen BERGwerk]F fanden die Kinder den Schatz.

(6.2.4.) [In einem vogtländischen BERGwerk]F fanden sie ihn.

In question-answer pairs sensu stricto (6.1.1), (6.1.2) the next speaker should not use the definite article or the pronoun with specific reference, for then he would give more information than he was asked for in (6.) Sentences in (6.2) are not answers sensu stricto.

But many of the characteristics of categorical sentences do not hold in corrections, for corrections have their own information structure, which will be explained next. 


\section{The information structure of corrections}

\subsection{Articles and movement}

Normally, corrections react to first sentences and therefore are backward-referring utterances. They may either keep the syntactic structure of first sentences or change it.

(5) [In einem vogtländischen Bergwerk fanden Kinder beim Spielen einen mittelalterlichen SILberschatz.]F

(5A) In einem vogtländischen Bergwerk fanden Kinder beim Spielen [Beutestücke aus dem zweiten WELTkrieg]KF.

(5A) keeps the constituent order of (5). But very often, the contrasted constituents are moved into Spec CP:

(5B) [Beutestücke aus dem zweiten WELTkrieg]KF fanden Kinder beim Spielen in einem vogtländischen Bergwerk.

Putting contrasted constituents into Spec $\mathrm{CP}$ follows the principle mentioned above when focussed constituents in the topic position of categorical sentences were explained. Second speakers begin increasing their speaking rate when they reach the non-corrected part identical with the first speaker's construction. Besides, it is normal that the non-corrected parts of the first sentence are pronominalized or left out, so that in the extreme case the ellipsis only consists of the domain of the contrastive focus. What was called the extreme case is normal usage in dialogs. ${ }^{4}$

(5B') [Beutestücke aus dem zweiten WELTkrieg]KF fanden Kinder / ... fanden sie dort / wurden gefunden.

(5C) [Beutestuicke aus dem zweiten WELTkrieg]KF (waren es). / Es waren [Beutestücke aus dem zweiten WELTkrieg]KF.

(5B') (Nein,) [Beutestücke aus dem zweiten WELTkrieg]KF.

(6) Die Kinder fanden beim Spielen [einen mittelalterlichen Silberschatz in einem vogtländischen BERGwerk]F.

(6A) Die Kinder fanden beim Spielen einen mittelalterlichen Silberschatz [in einem STEINbruch]KF.

(6B) Die Kinder fanden [in einem STEINbruch]KF beim Spielen einen mittelalterlichen Silberschatz.

In (6A) constituents with indefinite articles follow those with definite articles just like in categorical sentences. But (6B) violates several principles of information structure of German categorical sentences. Not only has the contrasted constituent been moved between background constituents, there is a definite DP following it, too. (6B), however, is a grammatically and information-structurally correct sentence. It proves that corrections have their own information structure. The constituent indexed by $[\ldots] \mathrm{KF}$ constitutes focus. The rest of the sentence automatically constitutes the background of the correction. Therefore the grammatical rules helping to divide categorial sentences into background and focus do not hold in corrections.

4 cf. Schwabe (2000): Coordinate Ellipsis and Information Structure. 
Besides, there are different reasons to change the articles in corrections. First, next speakers who correct may know the situation with all its participants. Therefore they can change articles for better knowledge of the referents of the DPs. In (6C), the DPs refer specifically. This is the kind of change of reference we forbade in question-answer pairs sensu stricto. The corrected constituent "im Kirchdorfer STEINbruch" in (6C) refers specifically as well.

(6C) Die Kinder fanden beim Spielen den mittelalterlichen Silberschatz [im Kirchdorfer STEINbruch]KF.

But the next speaker may also refer unspecifically with the constituent den mittelalterlichen Siberschatz when he uses (6C) as a sentence in a continuous text with (6C) following (6), and "the medieval treasure" being accepted as a discourse referent which had already been introduced by (6). This kind of change of articles which does not change reference was allowed in question-answer pairs sensu stricto above.

The Grammar of German forbids certain kinds of movements in categorical sentences or fully focussed sentences but allows them in corrections. The corrections in (7A) show the otherwise immovable entities as contrastively focussed constituents in Spec CP:

So-called unseparable prefixes:

(7.1 A) [AN]KF hat er das Licht gemacht, nicht aus.

infinite verb forms separated from their otherwise unseparable directional argument:

(7.2A) [GeSETZT]KF hat er den Stuhl auf die Terrasse, nicht geworfen.

infinite verb forms separated from their unseparable predicatives:

(7.3A) [GeWESen]KF ist er Lehrer, nicht geworden.

What is interesting but so far has not been explained is that the (parts of) constituents which may appear in Spec CP when contrastively focussed, are not allowed in the topic position of dependent clauses, i.e., directly behind $\mathrm{C}^{\circ}$ (cf. (7.3.1)), whereas their counterparts in doubly focussed constructions with the so-called Bridge Contour are allowed there, too, (cf. (7.4)).

(7.3.1A) Ich weiß, *daß geWEsen er Lehrer ist. /StuDIERT hat er LinGUIstik, /geWORden ist er dann ILEHrer. Ich weiß, dass /stuDIERT er LingUIstik hat, aber geWORden dann LEHrer ist.

Summary:

Examples (6B) through (6C) exemplify that what is new information in a correction need not conform to focus in categorical sentences, and what is background information in corrections does not correspond to background information in categorical sentences. In corrections, all the constituents of the first sentence which have not been protested against are accepted as 'background'. As far as corrections are concerned, we better put focus and background in inverted commas because they are defined by other grammatical means than focus and background in categorical sentences. 'Focus' is 
defined by the focus domain of contrastive focus. It is neither restricted to the focusable (sub-) constituents of a categorical sentence nor to their positions in categorical sentences. But the articles in 'focus' constituents do conform to the restrictions of focus constituents: definite articles in 'focus' refer uniquely only.

\subsection{The prosodic realization of contrastive focus}

The prosodic realization of contrastive focus deserves a paper of its own. But at least a few characteristics of contrastive pitch accent must be mentioned here in order to complete the model of correction presented in chapter 4.: There is a marked increase in frequency on the contrastively focussed syllable. It is true that the absolute value of frequency need not be much above that of presentational focus peaks; but this is compensated for by the often lower onsets of contours with contrastive focus relative to contours with presentational focus. Speakers seem to produce the clearest possible marking by means of least effort. Increase of frequency must be understood as relative not absolute increase. What else is remarkable is that the frequency peak is on the contrastively focussed syllable rather than before as is often the case with presentational focus. The prosodic marking is clearly audible and visible in its context. It is the formal representation of the linguistic sign 'contrastive focus'.

\subsection{The focus domain of contrastive focus}

\subsubsection{Focus induced by context only}

The next speaker can protest against a whole sentence. The sentence protested against and the next sentence must fit into the same context. Lang (1976) called this kind of context CI (common integrator) or in German GEI (gemeinsame Einordnungsinstanz).

(8.1) Warum redet denn Anna nicht mit ihren Kindern?

[Weil Peter nicht EINgekauft hat]F.

(8.1A) Nein, [weil die Tochter trotz ihres Hausarrests AUSgegangen ist]KF

In these examples, $\mathrm{CI}$ is a class of reproachable activities of Anna's children.

(8.2) Wo bleiben denn die Kinder?

Anna [ist im KIno]F

(8.2A) Sie [kauft für Oma EIN]KF

CI are the activities keeping a child from returning home in time.

The next speaker can also protest against any part of form and meaning of the sentence, against phrases, words, constituents of word formation or even against affixes or single sounds of words. The few German words like the impersonal pronoun man which cannot be stressed cannot express contrastive focus either except when their phonological form is protested against as in (8.3A).

(8.3) Men sitzt AUFrecht!

(8.3A) MAN! 
If the notion of $\mathrm{CI}$ is to be applied to examples like 8.3, it can only refer to a class of phonetic realizations of the vowel in the one-syllable word man. The kind of CI will be different once more in (8.4), where it comprises a class of dialectal variations of the impersonal pronoun man.

\section{(8.4) Mer sitzt AUFrecht!}

(8.4A) MAN!

To find out how large the respective focus domain is we have to compare the next sentence with the first sentence and define the focus domain subtractively:

(9) Warum wurde Anna nicht zum Nachbarschaftsfest eingeladen?

Es gibt Spannungen; denn sie [hat sich mit ihrem NACHbarn gestritten]F

(9A) sie hat ihren Nachbarn [SCHLECHT gemacht]KF

(9B) sie hat sich mit [ALlen]KF Nachbarn gestritten.

(9C) Anna hat sich mit ihrem Nachbar [ZERstritten]KF.

(9D) sie hat sich mit ihrem [NachBARN]KF zerstritten.

(9A) through (9D) form a series of corrections. (9A) protests against the meaning expressed by the predicate, (9B) against the quantification in the modifying PP, (9C) protests against a derived lexical entry, and (9D) corrects the morphological form of a word. Although in (9D) only one sound is concerned, the pitch accent is placed on a syllable, of course, and the minimal focus domain is a word or word form. To add emphasis to the correction, several contrastive foci may be used.

(9D') [NACH-BARN]KF.

(8A') Nein, weil [ihre Tochter - TROTZ - ihres HAUSarrests - AUSgegangen ist]KF.

What these examples show, too, is, that tuples of foci need not alter the focus domain.

Depending on context, a functionally or structurally ambiguous phrase may express more than one correction and even have different focus domains: Finite verbs, eg., express several kinds of meaning: the lexical meaning of the verb stem, temporal meaning, and sentence mood, and each of them can be protested against. Protest against sentence mood is called Verumfokus. Höhle (1982) showed how the corresponding contrastive foci are realized when synthetically or analytically constructed verb forms are used. When there is only one syllable available, contrastive focus is context dependent in three ways.

(10A) Peter hat [geSAGT]KF - protest against lexical meaning

Peter [HAT]KF gesagt - protest against tense

Peter [HAT]KF gesagt - Verumfokus $=$ protest against sentence mood.

(11A) Peter [SAGte]KF - protest against lexical meaning, or protest against sentence mood

Peter [sagTE]KF - protest against tense.

(12A) Peter [SAGT ]KF - protest against lexical meaning, or against tense, or against sentence mood. 
Finding out which kind of protest is relevant can only be found out by means of context.

Let us move to another obvious kind of context dependence of the focus domain: correction of coordinated constituents:

(13) Warum wurde Anna nicht zum Nachbarschaftsfest eingeladen? Es gibt Spannungen; denn Anna hat sich mit Klaus, Peter und Bert gestritten.

(13A) Sie hat sich mit Klaus, Peter und [OTTO]KF gestritten.

(13B1) Sie hat sich mit [Hans, Siegfried und OTTO]KF gestritten.

For (13B1) you might again find several contrastive foci in one focus domain.

(13B2) Sie hat sich mit [HANS, SIEGfried und OTTO]KF gestritten.

\subsubsection{Context-sensitive focus versus focus associated with operators}

It is well known that there is a class of focussing particles. The associated focus may be presentational focus (cf. (14)) as well as contrastive focus (cf. (14.1A)):

$\mathrm{Zu}$ unserem 20. Hochzeitstag hatten wir wieder unsere Kinder eingeladen. Ursprünglich wollten auch alle kommen. Aber es kommen nur [die SÖHne]F.

Zum 20. Hochzeitstag hatten die Müllers wieder ihre Kinder eingeladen. Es wollten auch alle kommen.

Nur [die SÖHne]KF. Hast Du denn noch nicht von dem enttäuschenden Brief ihrer Tochter Anja gehört?

Different from the examples with context-sensitive contrastive focus, example (14.1A) has its focus domain fixed by "nur", but its corrective meaning is context-dependent. When the focus-sensitive particle itself is protested against only contrastive focus is realized, and the correction is context-dependent. Cf. (14.2A).

Habe ich das richtig verstanden, ... auch [die SÖHne]F?

[NUR]KF die Söhne.

The sentence pairs in (14) deserve a detailed description and there are several in structured meaning semantics (cf. among others Jacobs (1982), Krifka (1998)) as well as in alternative semantics (cf. among others Rooth (1985), Rooth (1996)). This paper only wants to remind that they are associated with presentational as well as with contrastive focus. A second class of elements associated with focus which are of greater relevance for our subject are the focus-sensitive German operators nicht and sondern. But before we can discuss these we have to set up an explanatory frame: All the corrections hitherto spoken about are backward-referring corrections. The next speaker protests against an entity already given, and he proposes a marked replacement, whereby the negator nein is optional.

Peter [ist geKOMmen]F. (Nein.) [PAUL]KF ist gekommen.

A similar interpretation is achieved by a forward-referring correction by means of the focus sensitive operator nicht in the second conjunct of a coordination. 
(15.2A') [PAUL]KF ist gekommen, und nicht [PEter]F .

$\left(15.2 \mathrm{~A}^{\prime \prime}\right) \quad$ [PAUL]KF ist gekommen, und [NICHT]F Peter. ${ }^{5}$

Some more examples:

(16A) Petra Meier hat in dieser Saison im Eislaufen gute Chancen. Den [DREIfachen]KF Rittberger hat sie gestern gezeigt, nicht den doppelten aus ihrem normalen Kürprogramm.

(17A) Peter scheint recht egozentrisch zu sein. [AUFgestanden]KF ist er, [RAUSgerannt]KF, er [konnte die Aussprache nicht tollerieren]F.

A third variant are backward-referring corrections which have the German focussensitive operator sondern in the second conjunct and the focus-sensitive operator nicht in the first conjunct.

Peter ist [NICHT]KF gekommen, sondern [Paul]F ist gekommen. ${ }^{6}$

Some more examples:

(18A) Nicht [in einem vogtländischen BERGwerk]KF fanden die Kinder den mittelalterlichen Silberschatz, sondern [in einem Steinbruch]F.

(19A) Peter [konnte nicht länger ruhig SITzen bleiben]KF, sondern [ist AUFgestanden und RAUSgerannt]F

(20A) Es ist nicht, dass Peter die Aussprache nicht [AKzeptieren]KF konnte , sondern er konnte sie nicht [DURCHhalten]F. Er hat schlechte Nerven.

(21A) Nicht [den DOPpelten Rittberger]KF aus ihrem normalen Kürprogramm hat Petra Meier gestern gezeigt, sondern [den DRElfachen]F.

Examples with backward-referring context-sensitive corrections are often described in frameworks of information structure. Examples with focus-sensitive operators are a typical subject of semantics.

The three types of constructions have similar semantic interpretations but differ in certain structural as well as pragmatic respects. Let us begin with the latter:

- The sentences with focus-sensitive operators overtly negate the untrue or incorrect (part of a) sentence. Context-sensitive backward-referring corrections don't. They only consist of an overt replacement. But it is possible to add nein / nein, das stimmt nicht / nein, das ist nicht wahr / nein, das ist nicht korrekt (cf. (15.1A)). These are sentential utterances with das refering to the first sentence. Nicht, on the contrary, is an operator with a propositional domain and a focus of negation. What is in the scope of negation need not always be the focus of the sentence in terms of information structure. ${ }^{7}$ Because of the context-dependent interpretation of contrastive focus not every focusing nicht affects contrastive focus ${ }^{8}$. But any contrastive focus associated with nicht is its focus, of course. When nicht is in the first conjunct and the sentence has a sondern-clause as its

\footnotetext{
5 The second conjunct mostly is an elliptic construction.

6 The underlined words may be deleted when the second conjunct is an elliptic construction.

7 Cf. Wen kennt Luise nicht? [PEter]F kennt Luise nicht.

Scmantic paraphrase: There is an individual $x_{i}$ with the name of Peter for whom it is not true that Luise knows him .

8 Cf. Wann kommt denn Peter? Ich weiß nur soviel, er kommt nicht [im MAIF.
}

Nach dem letzen Anruf kommt er nicht [im MAI]KF, sondern [im JUni] F. 
second conjunct, the focus of nicht always is contrastive focus. This follows from the lexical meaning of nicht ..., sondern and can be used as a general test for contrastive focus which may be applied implicitly even to backward-referring context-sensitive corrections.

- The focus-sensitive operator nicht is not a truth functional operator. As Horn ${ }^{9}$ formulated it, nicht can be used as a so-called metalinguistic negation correcting not only semantic (and among those not only the ones fulfilling the definition of classical negation) but all the other properties of sentences - just like corrections.

- "sondern" fixes its focus domain and - indirectly - the focus domain of the contrastive focus in the preceding main clause, too, because what is in the domain of presentational focus of "sondern" is the (part of the) constituent to replace the contrastively marked (part of the) constituent in the first conjunct. ${ }^{10}$ In context-sensitive backward-referring corrections as well as in forward-referring constructions with focussensitive nicht in the first conjunct on the contrary, the focus domain can be fixed only by means of the context by subtracting the identical 'background' constituents and comparing the 'foci'. Therefore, when context-sensitive backward-referring corrections cannot be uttered immediately after the corresponding first sentence it is useful for the second speaker to overtly refer back and remind the communicative partners of the form and content of the first sentence to be corrected by him.

(22) Du hast vorhin gesagt, PEter sei gekommen. (Das stimmt nicht.) [PAUL]KF ist gekommen.

- Form and usage of the different correction-constructions coincide. Whereas backward-referring corrections normally appear in dialogs, forward-referring corrections and "nicht ... sondern"-constructions are preferably used in monological speech. The speaker contrastively announces a) what he considers more correct than the corresponding entity in the following negative clause (forward correction) or b) what he himself will correct afterwards (by means of "sondern"). The speaker may either overtly refer to an utterance of a first speaker which he intends to correct, or he may increase attention by negating certain possibilities and arguing in favor of the other. Backwardreferring context-sensitive corrections correct utterances of partners as soon as it is the next speakers turn.

- Just as focus-sensitive particles and nicht can be associated with contrastive focus "sondern" can, too. (cf. (23) and (23A)).

(23) Nicht [den DOPpelten Rittberger]KF aus ihrem normalen Kürprogramm hat Petra Meier gestern gezeigt, sondern [den DREIfachen]F.

(23A) sondern [den dreieinHALBfachen]KF.

- How is it possible for backward-referring context-sensitive corrections to do without overt negation? The explanation partly depends on the meaning of contrastive focus and partly is pragmatically based and depends on knowledge about the sequencing of sentences in different types of texts which will be explained in chapter 4 . In this chapter we only want to show that there is a difference in meaning between sequences of sentences with presentational and with contrastive focus.

9 Cf. Horn (1985): Metalinguistic Negation and Pragmatic Ambiguity.

${ }^{10}$ Cf. Lang (1984): The Semantics of Coordination. 
Speaker A: [Peter hat sich eine GaRAge gekauft]F.

Speaker B: [Seine Frau hat sich ein AUto gekauft]F.

Normally, the communicative partners interpret this sequence of sentences in a way that both statements are true. In their common ground, the garage as well as the car belong to the property of the couple.

(23A) Speaker A: Peter [hat sich eine GaRAge gekauft]F.

Speaker B: [Seine Frau hat sich ein AUto gekauft]KF.

Normally, the communicative partners interpret the sentence of speaker B as a correction of the utterance of speaker A. It is not true, that a garage was bought by Peter. What holds is that his wife bought a car. As both sequences of sentences only differ in the prosodic contour, the difference in meaning must depend on contrastive focus. In 3.4 we will explain, that contrastive focus is a linguistic sign with a characteristic prosodic realization and a systematic meaning. Its meaning will be characterized as an existentially bound proposition: there is an element in the grammatical representation of the first sentence not identical with the contextually marked one in the next sentence, but both fit in the same CI and belong to equivalent focus domains. Correspondingly, contrastive focus cannot be reduced to a prosodically deviant placement of word stress or phrasal stress. Cf. (24).

(24) I'll tell you a joke.: [An AMErican farmer met a CaNAdian farmer]F. Said the AMErican farmer to the CaNAdian farmer: ...

In a fully focused sentence at the beginning of a text, presentational focus is not realized in the Determiner Phrase constituting the subject of the sentence, and it is not realized on the adjective either. But we know, too, that a sentence can contain multiple foci. The reasons are manifold. In (24) we are confronted with two presentational foci affected by grammatical parallelism. It is a kind of constructively determined focus. In conformity with context, we find constructively determined contrastive focus, too.

(24A) No, it happened in the old world: [A DAnish farmer met an ENGlish farmer]KF.

(24) contains a syntactic construction parallel to that of (24A). But only (24A) can be interpreted as a correction. This supports the conclusion that contrastive focus is a linguistic sign which correlates a characteristic form with a characteristic meaning. Its formal semantic description will be explained below.

\subsection{Semantic Form of corrections}

In this chapter we will only speak about context-sensitive backward-referring corrections. Different semantic theories treat the phenomenon of meaning differently. In this paper, meaning is understood as being separable into Semantic Form (part of linguistic knowledge) and context (conceptual structures). ${ }^{1 /}$ The Semantic Form (SF) of a sentence is compositionally constructed out of the underspecified SFs of words and affixes on the basis of syntactic surface structure. The SFs of sentences are interpreted

"cf. M. Bierwisch, E. Lang (eds) 1987: Grammatische und konzeptuelle Aspekte von Dimensionsadjektiven.

D. Wunderlich; Cause and the structure of verbs. 
in context. We leave it open here whether it is possible to compose fully underspecified meanings of sentences or whether semantic composition and interpretation necessarily intersect. ${ }^{12}$ In this chapter the meaning of a sentence represented with contrastive focus is exemplified by the simple example [HANS] KF kommt in dialogue (25) $-(25 \mathrm{~A})$.

(25) Wer hat sich denn nun tatsächlich alles angemeldet?

Peter [KOMMT]F.

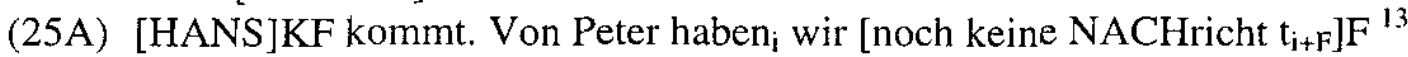

The SF of [HANS]KF kommt consists of an assertive proposition plus an existentially bound proposition, the meaning of contrastive focus. The assertive part is compositionally constructed out of the SFs of the lexical entries of words and affixes ${ }^{14}$. Therefore, we may consider this framework a variant of structured meaning semantics the different authors of which used different means to compose the assertive meaning of the sentence.

(i) Hans: $\varepsilon x[[[$ Person, $\mathrm{x}]:[\mathrm{MALE}, \mathrm{x}]]:$ [Name, $\mathrm{x}$, Hans $]]$

The SF of the sentence has to reflect the information structure of the sentence. Being contrasted, Hans is not the topic of the sentence. Its SF is constructed by means of the epsilon operator and becomes a semantic argument of komm-. ${ }^{15}$

(ii) komm-: $\lambda \mathrm{x} \lambda \mathrm{T} \lambda \mathrm{s}[\mathrm{s}$ INST [KOMM, $\mathrm{x}, \mathrm{T}]]$

(iii) Future Tense: $\lambda \mathrm{P}\left[\mathrm{P}\left[\varepsilon \mathrm{T}^{\prime}:\left[\mathrm{T}^{\prime} \mathrm{NACH} \mathrm{T}^{\circ}\right]\right]\right]$

(iv) Assertive Mood: $\lambda \mathrm{P} \exists \mathrm{s}[\mathrm{P}, \mathrm{s}]$

When information structure is paid attention to in the SF of the sentence it has to be mapped on the syntactic surface structure. This affords several type shifts for the LEs to be properly composed. ${ }^{16}$

(v) S-Structure

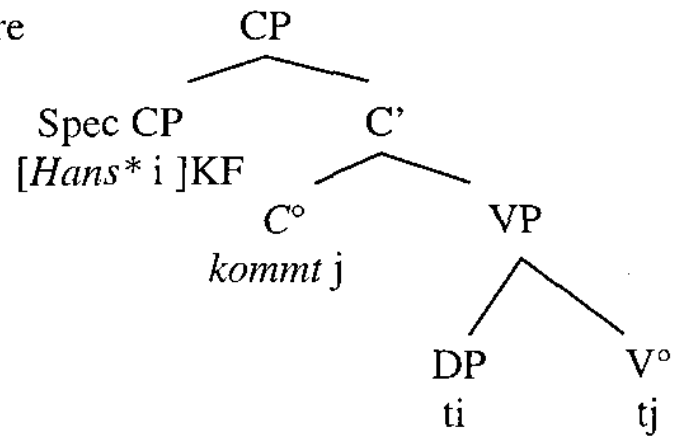

12 The latter is practiced by J. Dölling in several papers. Cf. e.g., Dölling (1997): Semantic Form and Abductive Fixation of Parameters.

13 German verbs are moved for syntactic reasons independent of whether they are focus or background constituents. Traces in the focus domain indexed by $+\mathrm{F}$ indicate that their antecedents are part of the focus of the sentence.

14 Affixes are lexical entries. Cf. Chapter 4.

15 Cf. Steube (2000): Ein kognitionswissenschaftlich basiertes Modell für die Informationsstrukturierung (in Anwendung auf das Deutsche).

Späth (in preparation): Satzbedeutung und Informationsstruktur. Zur Semantischen Komposition prosodisch unmarkierter Satzstrukturen.

16 cf. Partee (1986): Noun Phrase Interpretation and Type-Shifting Principles. 
The SF of the assertive part of the sentence is:

(vi) $\exists \mathrm{s}[\mathrm{s}$ INST [KOMM, $\varepsilon \mathrm{x}[[[$ Person, $\mathrm{x}]:[$ MALE, $\mathrm{x}]]$ : [Name, $\mathrm{x}$, Hans $]], \varepsilon \mathrm{T}^{\prime}$ :

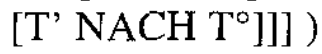

Realizing contrastive pitch accent Hans is in the focus domain. And the meaning of Hans is the 'content' of contrastive focus. The meaning of contrastive focus is considered to be the SF of a separate LE which is conjunctively added to the SF of the assertive part of the meaning of the sentence. It has a general format with a variable which can be replaced by any contrasted element in the grammatical description of a correction. In (25A) the SF of Hans replaces the variable in the SF of contrastive focus.

$$
\lambda \mathrm{p}[\mathrm{p}] \wedge \exists ! \mathrm{y}, \mathrm{s}_{\mathrm{I}}\left[\mathrm{s}_{1} \text { represented by } \mathrm{S}_{\mathrm{I}}=\left(\mathrm{s} \ldots[\text { HANS/y }]_{\text {focus domain }} \ldots\right)\right]^{17}
$$

to be read: a proposition $\mathrm{p}$ and exactly one $\mathrm{y}$, exactly one situation $s_{1}$ so that $s_{1}$ is represented by the first sentence $S_{1}$ which equals the next sentence $S$ except that Hans replaces y, and Hans, y constitute identical focus domains. In example (25) : y = Peter. After replacing $\mathrm{p}$ in the meaning of contrastive focus by the SF of the assertive part of the next sentence, we get:

(viii) $\exists \mathrm{s}$ [s INST [KOMM, ex [[[Person, $\mathrm{x}]:$ [MALE, $\mathrm{x}]]$ : [Name, $\mathrm{x}$, Hans]], $\varepsilon \mathrm{T}$ ': $\left.\left.\left[\mathrm{T}^{\prime} \mathrm{NACH} \mathrm{T}^{\circ}\right]\right]\right] \wedge \exists ! \mathrm{y}, \mathrm{s}_{1}\left[\mathrm{~s}_{1}\right.$ represented by $\left.\mathrm{S}_{1}=\left(\mathrm{s} \ldots[\text { Hans } / \mathrm{y}]_{\text {focus domain }} . ..\right)\right]$

The SF of the contrastively focused sentence is underspecified very much. The communicative partners have to make out what is the first sentence and what is the next sentence by noticing which parts of the two sentences are equal and which part of the first sentence is intended to be replaced by which one of the next sentence, both constituting (part of) an identical focus domain. This way, the meaning of contrastive focus brings about textual coherence between the contrastively marked sentence and the first sentence. But even this interpretation is underspecified as far as the underlying negation of the first sentence is concerned. This pragmatic problem will be solved in chapter 4 .

\section{A model for sentences with contrastive focus as their only focus marking}

In his book "Speaking: From Intention to Articulation" (1989), Levelt introduced two cognitive levels. Cognition 1 is responsible for the planning of the whole text, of its type, of the way it can be presented to the relevant communicative partners. Likewise, Cognition 1 is responsible for the general principles of textual coherence. As far as our question is concerned, Cognition 1 is responsible for the sequencing of information and for the interaction of first and next speakers in a broad sense.

17 There is a discussion on what the semantic relation between the assertive part of the compositionally constructed meaning of a sentence and the meaning of contrastive focus is. For Dölling (1988) and in this paper the meaning of contrastive focus is an integral part of the meaning of the whole sentence and belongs to SF. Because of the examples with metalinguistic negation, Jacobs (1982) argued that it is an implication and not a presupposition. Rooth (1996) argues against the status of existential presuppositions, too because presuppositions should project what they don't do in all contexts. And in chapter 1 the interpretation of corrections was explained as fundamentally context-dependent. Our theory must further argue against presuppositions because they are doubtful SF constituents. 
Cognition 2 constitutes the interface to the level of formulation (= grammar). According to Levelt, in Cognition 2 the information is represented in a propositional format, and it is prestructured by information structural categories. Cognition 2 marks the pieces of information which will become the topic and the comment, the background and the focus of the following sentence dependent on its backward context. There is a pragmatic principle that no proposition to be verbalized by grammar is without new information. Therefore each proposition to be verbalized in a sequence will enlarge common ground as long as it is not explicitly blocked. Corrections do so and propose explicit replacements. If a corrections is not protested against in its turn its 'focus' will become part of common ground, too. On the basis of this principle backward-directed corrections need not explicitly negate the corrected part of information. But forwarddirected corrections produced by the same speaker must do so. This pragmatic principle includes the pragmatic explanation for the difference between backward-directed corrections and nicht ... sondern constructions. Nicht ... sondern constructions explicitly express what context-sensitive background-referring corrections only imply.

The cognitive categories are mapped onto the grammatical categories of the different levels of grammar which will realize them. The mapping of cognitive structures onto grammatical structures is achieved via the lexicon, since meanings (Semantic Forms) are underspecified constructions of cognitive primitives. The SFs of words and affixes contain all the entries necessary for their combination into Semantic Forms of sentences. As mentioned above, information structure is part of the object of semantics since it has an influence on the truth conditions and on the conditions of use of sentences $^{18}$. The SFs of sentences are mapped onto syntactic surface structures. The latter follow the principles of information structure, too because the relevant cognitive markings like topic, comment, background, and focus which have been transmitted from Cognition 2 to all the grammatical levels passed so far will partly be realized by syntactic means as well. From syntax, these cognitive categories will be further transmitted to the levels of morphology and phonology to be formally realized there, too, whenever these formal means are relevant and, therefore, marked on those levels.

Dealing with sentences in which contrastive focus is the only focus marking, we noticed that the only cognitive categories relevant for corrections are topic and focus: therefore contrastive focus and its focus domain are marked (the rest is automatically interpreted as belonging to background); and it is necessary to mark topics because they have an influence on the structuring and on the type of a text. The rest is automatically interpreted as comment. Let us exemplify the model of sentences with contrastive focus by (26) and (26A) and begin with the cognitive level of Cognition 2 :

(26) Wer hat sich denn nun tatsächlich alles angemeldet?

Peter [KOMMT]F.

(26A) [HANS]KF kommt. Von Peter [haben wir noch keine NACHricht.]F

Cognition 2:

(26) Peter [KOMMT]F:

(ix) Discourse referents: $\mathrm{x}, \mathrm{s}, \mathrm{T}$

Cognitive representation: $\operatorname{PETER}=\mathrm{x} \wedge[\operatorname{KOMM}(\mathrm{x}$, Future, $\mathrm{s})] \mathrm{F}$ $+\mathrm{T}$

18 Cf. footnote 14. 
(26A) [HANS]KF kommt.

(x) Discourse referents: $\mathrm{x}, \mathrm{s}, \mathrm{T}$

Cognitive representation: $([\mathrm{HANS}] \mathrm{KF}=\mathrm{x} \wedge \mathrm{KOMM}(\mathrm{x}, \text { Future, } \mathrm{s}))^{*}$

On the level of Cognition 2, the Topic- and Focus-parts of the proposition to be verbalized are marked, and the entire proposition is marked by an asterisc as a correction. The correction mark on the level of Cognition 2 merely expresses that the marked proposition interrupts the sequence of presentation of information and protests against a verbalized information already given.

The mark has to be realized grammatically and is transmitted to the relevant levels of grammar. As the correction-mark has a formal and a semantic realization, there must be several places where grammar has to take notice of it:

1.1 by the context-dependent fixation of the focus domain on all levels of grammar

1.2 by the phonological realization of the prosodic contour, especially on the contrastively marked syllable in the focus domain

2. by marking the syntactic or semantic, morphological or phonological 'content' of the lexical entry (or its projection) which is protested against

3. by adding the SF of contrastive focus to the SF of the sentence.

We will exemplify the grammatically relevant properties of example (26A).

Each lexical entry has its SF, GF (grammatical form), and PF (phonological form).

1. Hans will be represented as follows:

(xi) GF: $[+\mathrm{N},-\mathrm{V}]$

$[+$ specific $]$

[proper name]

(xii) SF: $\varepsilon x[[[$ Person, $\mathrm{x}]:[$ MALE, $\mathrm{x}]]:[$ Name, $\mathrm{x}$, Hans $]]$ *

Correction (26A) protests against the SF of Peter, and therefore the SF of Hans must be marked as (part of) the 'content' of the SF of contrastive focus.

(xiii) PF of the sentence : [ /hans/ ]KF / kommt/

In the prosodic contour of the sentence contrastive focus is realized on Hans. Therefore the mark KF. The focus domain has been indicated by angled brackets.

2. Hans is the subject of komm. Komm- is an intransitive verb; its noun phrase in subject position has nominative case and bears theta role 1 (the role of agent).

(xiv) GF: $[+\mathrm{V},-\mathrm{N}]$

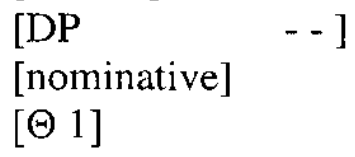

These grammatical features must correspond to those in the theta grid of the SF of komm-. 
(xv)

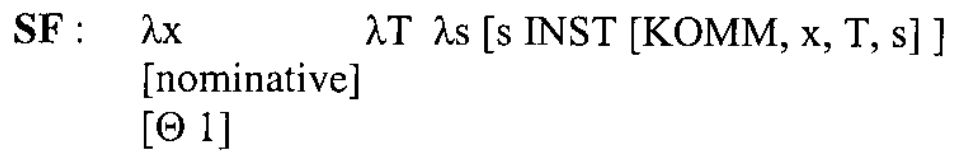

In 3.4 we exemplified how the meanings of the lexical entries are compositionally constructed to form the SF of the sentence and how the SF of contrastive focus is added to the assertive part of the meaning of the correction. We need not repeat that here.

Next we would like to give an example with a correction directed to a formal feature of a word:

(27) Sieh mal, [Anna grüßt den NACHbar wieder]F.

(27A) Anna grüßt den [NachBARN]KF wieder.

To find out what the second speaker protests against, let us first look at the SF of grüß-:

(xvi) SF: $\lambda y \quad \lambda x \quad \lambda T \lambda s$ [s INST [GRÜSS- $x, y, T]$ ]

$[$ Acc $][\mathrm{Nom}]$

$[\Theta 2][\Theta 1]$

The oblique argument is characterized by the theta role THEME and by accusative case. DPs replacing the variable $\mathrm{y}$ must fulfill these conditions. Declension class $\mathrm{i}$ in the GF of Nachbar $[+\mathrm{N},-\mathrm{V}$, masculine, declension class i] is responsible for the way the lexical entry of the ending [accusative case, singular] of Nachbar is phonologically realized. Like the other oblique cases and the nominative plural of Nachbar it has to be realized by / $n$ / and not by zero as in (27).

Our lexicon contains entries of the endings, too. The characteristics of the ending and of the stem must agree.

(xvii) GF of ending: [Acc]

[sg]

[declension class i]

[masculine]

(xviii) PF of that ending: $/-n / *$.

The PF of the corresponding ending is marked by *. This ending has an empty SF. Therefore, the correction is directed to the formal representation of the wordform. Example (27A) shows that the variable in the SF of contrastive focus may be replaced by a grammatical element represented on a level other than SF. In view of examples like this, the SF of contrastive focus was formulated by means of the relation "sentence 1 is represented by $S_{1}$ " and not by means of the relation "the situation $S_{1}$ is an instance of the proposition ..." often used in two-level semantics (cf. the SF of komm-).

We have to generalize the correction [HANS]KF and build up a correction format containing a variable to be replaced by any grammatically categorized element. The categorical structure of the SF of contrastive focus and the way it is combined with the $\mathrm{SF}$ of the affirmative part of next sentence, however, remain as before. 
Generalized SF of contrastive focus (version 1):

(xix) $\lambda \mathrm{p}[\mathrm{p}] \wedge \exists ! \Phi, \mathrm{s}_{1}\left[\mathrm{~s}_{1} \text { represented by } \mathrm{S}_{1}=\left(\mathrm{s} \ldots[\Psi / \Phi]_{\text {focus domain }} \ldots\right)\right]^{19}$ Whereby:

$S_{1}=$ first sentence

$S=$ next sentence

$s_{1}=$ the situation spoken about by the first sentence

$\Psi$ the entity in the next sentence realizing contrastive pitch accent $\Psi$, $\Phi$ have the same CI.

$\mathrm{p}=$ compositionally constructed assertive SF of next sentence.

Gerhild Zybatow made me aware of the fact that corrections, however, react not only on utterances but even on implicit information the next speaker has reason to assume that it is part of the incorrect common ground of his partners. In cases like these the formalization by means of "the situation is an instance of the proposition ..." would be best. Therefore, dependent on the respective context, the SF of contrastive focus should either contain the predication "represented by $S_{1}$ " or the predication "is an instance of a proposition". The variable for both predications is $\mathrm{P}$ :

Generalized SF of contrastive focus (version 2):

(xx) $\lambda \mathrm{p}[\mathrm{p}] \wedge \exists ! \Phi, \mathrm{s}_{1}\left[\left[\mathrm{P}, \mathrm{s}_{1}\right]=\left(\Sigma \ldots[\Psi / \Phi]_{\text {focus domain } \ldots)}\right.\right.$... whereby :

dependent on $\mathrm{P}, \Sigma$ either is $\mathrm{S}$ or the proposition $\mathrm{p}$ of the next sentence.

Finally, we will sum up the different ways of markings which are necessary for corrections:

- On the level of cognition 2 the whole proposition to be verbalized is marked, because corrections do not constitute normal representative speech acts in so far as they do not obey the rules for continuous presentation of information.

- The extension of the focus domain is fixed by context and discovered by comparing the identical parts of the first and the next sentence and subtracting the focus domain from these. The focus domain is marked by angled brackets and by the sign KF. The minimum focus domain is a word or wordform. That means that the next speaker does not protest against e.g., an isolated bound morpheme but against the way a special LE has its affix realized. The next speaker does not protest against a connotation either, but he protests against a connotatively incorrect wordform or its projection.

- The marked syllable by which contrastive focus is prosodically realized need not agree with the position of word accent or phrasal accent. If the contrasted word had been Peter, a disyllabic word, its PF would normally realize KF on the accentuated first syllable but keep the whole word within the focus domain.

\section{(xxi) PF: [/PE - ter / ] \\ $\mathrm{KF}$}

Only when the second syllable had to be corrected by contrastive focus - i.e. in order to protest against a form like Pedro - word accent would not become contrastive focus:

cf. [/pe - TER/] KF/.

[The AMErican soldier] $\mathrm{KF}$ is an example for the possible disagreement between the actual position of KF and the normal position of phrasal accent. When KF is expressed in the normal focus position of the phrase the American SOLdier, contrastive focus

19 Neither in this nor in any other representation of this paper does the existential operator express existential force. 
alone is not able to fix the focus domain. The American SOLdier is ambiguous between narrow focus on [SOLdier] KF and phrasal focus [the American SOLdier]KF.

- Beside the formal properties of the correction sign, the 'content' of the SF of contrastive focus must be marked. It is found in the SF, GF or PF of a lexical entry or of its projection. The 'content' replaces the variable $\Phi$ in the SF of contrastive focus.

The formal side of the LE of contrastive focus is a relatively constant prosodic contour, and its SF has a generalized format the variables $P, \Phi$ and $\Psi$ of which are replaced in accord with the corrected element and the cognitive or grammatical level of its description.

\section{References:}

Alter, K.; Mleinek, I.; Rohe, T.; Steube, A; Umbach, C. (2001): Contrastive focus in speech production and perception. Paper read at the linguistic workshop "Kontrast 2", Leipzig 8.6.2001. To appear in: Linguistische Arbeitsberichte 77, Leipzig

Bierwisch, M.; Lang, E. (eds) (1987): Grammatische und konzeptuelle Aspekte von Dimensionsadjektiven (= studia grammatica 26, 27). Berlin: Akademie-Verlag

Dölling, J. (1988): Logische und semantische Aspekte der Negation. In: Linguistische Studien Reihe A 182, 1-104. Berlin: Akademie der Wiss. der DDR

Dölling, J. (1997): Semantic Form and Abductive Fixation of Parameters. In: van der Sandt, R.; Blutner, R.; Bierwisch, M. (eds): From Underspecification to Interpretation. Working Papers of the Institute for Logic and Linguistics, 113-138. IBM Deutschland. Heidelberg

Féry, C. (1993): German Intonational Patterns ( = Linguistische Arbeiten 285). Tübingen: Niemeyer

Herweg, M.; Maienborn, C. (1992): Konzept, Kontext, Bedeutung - zur Rolle der Zweiebenensemantik in einem Modell der Sprachproduktion. In: M. Herweg (ed): Hamburger Arbeitspapiere zur Sprachproduktion 1

Höhle, T.S. (1992): Über Verum-Fokus im Deutschen. In: J. Jacobs (ed.): Informationsstruktur und Grammatik, 112-141. Opladen: Westdeutscher Verlag

Horn, L. (1985): Metalinguistic Negation and Pragmatic Ambiguity. In: Language 61, 121-174

Jacobs, J. (1982): Syntax und Semantik der Negation im Deutschen ( = Studien zur theoretischen Linguistik 1). München: Fink

Krifka, M. (1998): Scope Inversion under the Rise-Fall Contour in German. In: Linguistic Inquiry 29, Nr. $1,75-112$

E. Lang (1976): Erklärungstexte, in: Daneš, F.; Viehweger, D. (eds): Probleme der Textgrammatik (=studia grammatica XI), 147-181, Berlin: Akademie-Verlag

Lang. E. (1984): The Semantics of Coordination (= SLCS 9). Amsterdam: Benjamins

Levelt, W. (1989): Speaking, From Intention to Articulation. Cambridge/Mass.

Partee, B. (1986): Noun Phrase Interpretation and Type Shifting Principles. In: Groenendijk, J.; de Jongh, D.; Stokhof, M. (eds): Studies in Discourse Representation Theory and the Theory of Generalized Quantifiers, 115-143. Dordrecht: Foris

Pasch, R. (1983): Mechanismen der inhaltlichen Gliederung von Sätzen: In: Rủžička, R.; Motsch, W. (eds): Untersuchungen zur Semantik ( = studia grammatica 22), 261-304. Berlin: Akademie-Verlag

Reis, M.; Rosengren, I. (1997): A Modular Approach to the Grammar of Additive Particles: the Case of German "AUCH". In: Journal of Semantics 14/4,1-77.

Rooth, M. (1985): Association with Focus. PhDiss. University of Massachusetts at Amherst

Rooth, M. (1996): Focus. In: Lapin, Sh. (ed.): The Handbook of Contemporary Semantic Theory, chapter 10. Oxford: Blackwell

Schwabe, K. (2000): Coordinate Ellipsis and Information Structure. In: Schwabe, K.; Zhang, N. (eds): Ellipsis in Conjunction ( = Linguitische Arbeiten 418). Tübingen: Niemeyer

Schwarzschild, R.: Interpreting Accent, in: http://www.rci.rutgers.edu/ tapuz/

Späth, A. (in preparation): Satzbedeutung und Informationsstruktur. Zur Semantischen Komposition prosodisch unmarkierter Satzstrukturen. Paper read at the linguistic conference „Topik-KommentarStruktur", Wuppertal 17.-18.11.2000. 
Steube, A. (2000): Ein kognitionswissenschaftlich basiertes Modell für die Informationsstrukturierung (in Anwendung auf das Deutsche). In: Bayer, J.; Römer, Ch. (eds): Von der Philologie zur Grammatiktheorie. Tübingen: Niemeyer

Umbach, C. (2001):Zur Semantik von Kontrastfokus. Paper read at the linguistic workshop "Kontrast 2", Leipzig 8.6.2001. To appear in: Linguistische Arbeitsberichte 77, Leipzig

Wunderlich, D. (1997): Cause and the Structure of Verbs. Linguistic Inquiry 28, 27-68. 